\title{
STRATEGY OF EMPOWERMENT SMALL AND MEDIUM EN- TERPRISES IN THE EFFORT FOR INCREASING REVENUE AND MARKET
}

\author{
Prasetio Ariwibowo \\ Faculty of Education and Social Sciences \\ Indraprasta PGRI University Jakarta \\ Prasetio.ariwibowo@yahoo.com
}

\begin{abstract}
The development of SMEs sector, explicitly aimed at the efforts to realize the power of the nation-competitiveness in order to strengthen the global competitive economy. This research uses qualitative descriptive method to describe each variable analyzed. The analysis is SWOT analysis and Analytical Hierarchy Procees (AHP) to calculate any case the most preferred and influence the development of the empowerment of SMEs especially in terms of revenue and market expansion in Semarang based and questionnaire that sample scrambled by the author.

Objectives and results of this study is to determine the priority of the strategy used by the Semarang city government and become the main reference for entrepreneurs of SMEs in Semarang to increase revenue and market share in the city of Semarang is improving managerial skills by improving capacity, work ethic, and the performance of the institution and the staff of the local government of Semarang, and increase community participation in the planning, implementation, and monitoring of development of SMEs.
\end{abstract}

\section{Keywords:}

Strategies to increase market share and revenue, SMEs, SWOT (Strength, Weakness, Opportunity, Threat) and AHP (Analytical Hierarchy Process).

Received: 30 January 2018 ;

Accepted: 31 January 2018;

Publish; April 2018

\section{How to Cite:}

Ariwibowo. P.. (2018). Strategy Of Empowerment Small And Medium Enterprises In The Effort For Increasing Revenue And Market. Econosains, 16(1), P 35-47 


\section{INTRODUCTION}

Development is an effort to improve the quality and life of the people of Indonesia, which is conducted continuously, based on the ability of the region to take advantage of the progress of Science Technology (Science and Technology) and with regard to global development challenges. The success of regional development is determined by the availability of natural resources are limited and qualified human resources by physically tough, mentally strong, excellent health and a master of science and technology. Quality human resources is an important factor in improving productivity and competitiveness of the region. In this case, capital and human resources, science and technology, and venture capital is a basic requirement MSME entrepreneurs in any area.

Problems facing SMEs today need a solution that the thinking between the government and business solutions MSMEs themselves. A policy the authority held by the government (the Semarang City Government and the Department of Cooperatives and SMEs Semarang) should always follow the wishes of the MSMEs in business. to deal with the problems of SMEs in the city of Semarang. Related to external factors and internal to the problems of SMEs, Musran Munizu (2010) stated that external factors have a significant and positive impact on the performance of micro and small enterprises, contributing 0.254 or $25.4 \%$. While internal factors have a significant and positive impact on the performance of micro and small enterprises with a contribution of 0.792 or $79.2 \%$. Based on these results indicate that internal factors have a greater influence on the performance of micro and small enterprises.

Based on the above, the authors are interested in doing research with the title Empowerment Development Strat- egy, Micro, Small and Medium Enterprises (MSMEs) in Improving Revenue and Market Expansion in Semarang.

a. Theoretical Study And Development Hypothesis

In accordance with Undang- Undang No. 20 Tahun 2008 about Micro, Small and Medium Enterprises (MSMEs). Micro business is a productive enterprise belonging to individuals and / or entities that meet the criteria of individual businesses micro enterprises as stipulated in this Law. Small Business is an economic enterprise productive stand-alone, conducted by an individual or business entity that is not a subsidiary or not a branch of the company owned, controlled, or be a part either directly or indirectly from medium or large businesses that meet the criteria of business small as defined in this Act. Medium-sized businesses are productive economic activities that stand alone, carried out by people individual or business entity that is not subsidiaries or branches of companies owned, controlled, or be a part either directly or indirectly by the Small Business or large enterprise with total net assets or annual sales revenue as stipulated in this Law.

According to Glueck and Jauch (2000), Strategy is an integrated, comprehensive and integrated strategic advantages that connects companies with environmental challenges and are designed to ensure that the main purpose of the company that can be achieved through proper execution by the organization. According to Strickland (in Winardi, 2004), the organization's strategy consists of actions and approaches to business, which is implemented by the management in order to achieve organizational performance set earlier. 
b. Research Objectives

This study was conducted to analyze the condition of market development for MSME entrepreneurs in marketing their products, especially in the trade sector in the city of Semarang and formulate recommendations implementation strategy to increase revenue and market expansion to the development of MSME in trade in Semarang in future.

c. Scope of the Study

This study focused on the analysis of the development strategy of empowerment of SMEs in the city of Semarang. Respondents were officials with the structural position of at least echelon four working units/ Satuan Kerja Perangkat Daerah (SKPD) Government of Semarang, the Office of SMEs and cooperatives in Central Java and 20 MSME's in trade both trade in goods / raw materials (crude), the trade of intermediate goods, as well as finished goods trade, services trade and located in the city of Semarang.

\section{LITERATURE REVIEW}

a. Micro Small and Medium Enterprises

Small and Medium Enterprises (SMEs) have varying limitations. According to Law No. 20 Year 2008 on Micro, Small and Medium Business Chapter IV Article 6 on the criteria of UMKM is as follows:

1. The Micro Business Criteria are:

a. Have a net worth of at most Rp. 50,000,000.00 (fifty million rupiah) excluding land and building of business premises.

b. Have annual sales of at most Rp. 300,000,000.00 (three hundred million rupiah).

2. Small Business Criteria are: a. Have a net worth of more than Rp. 50,000,000.00 (fifty million rupiah) up to a maximum of Rp. 500,000,000.00 (five hundred million rupiah) excluding land and building of business premises.

b. Have annual sales of more than Rp. 300,000,000.00 (three hundred million rupiah) up to a maximum of $\mathrm{Rp}$. 2.500.000.000,00 (two billion five hundred million rupiah).

3. Medium Business Criteria are:

a. Have net worth more than Rp. 500,000,000.00 (five hundred million rupiah) up to a maximum of Rp. $10,000,000,000.00$ (ten billion rupiah) excluding land and building of business premises.

b. Have annual sales of more than Rp. 2.500.000.000,00 (two billion five hundred million rupiah)

\section{b. Strategy}

According to Glueck \& Jauch (2000), strategy is a means used to achieve the ultimate goal (goal). Strategy is a unified, broad and integrated plan that connects the company's strategic advantage with the environmental challenges and is designed to ensure that the company's ultimate goal can be achieved through proper implementation by the organization. According to Strickland (in Winardi, 2004), the organizational strategy consists of actions and business approaches, implemented by the management to achieve pre-defined organizational performance. So, management strategy is a process by integrating the internal and external conditions of the company to achieve long-term corporate goals. 
c. SWOT Analysis

SWOT analysis (Strength, Weakness, Opportunities, Threats) is the systematic identification of various factors to formulate an organization's strategy. This analysis is based on logic that can maximize strength and opportunity, but can simultaneously minimize weakness and threats.

David (2006) states that the SWOT matrix can be used to formulate the company's future strategy. The SWOT matrix can generate four possible strategies: (a) SO strategy (Strenghts-Opportunities), a strategy that uses the power it has to take advantage of. (b) ST strategy (Strenghts-Threats) is a strategy that uses the power to avoid and overcome threats. (c) WO (WeaknessOpportunities) Strategy as a strategy that uses opportunities to overcome weaknesses. (d) WT Strategy (Weakness-Threats) is a strategy to minimize weaknesses and avoid threats.

\section{d. Analythical Hierarchy Process} (AHP)

Analitycal Hierarchy Process (AHP) is a functional hierarchy with the main input of human perception. Through a hierarchy, a complex and unstructured problem can be solved into groups which are then organized into a hierarchical form (Permadi, 1992).

The process that must be done in the analysis with AHP, as follows (Ma'arif and Tanjung, 2003): (1) Identification system is done to determine the problems to be solved in the form of goals (goals) to achieve, factors / criteria to be used, the actors involved in the system and its goals, and the strategic alternatives. (2) Preparation of hierarchy is done by abstracting the components on the system.
This abstraction must be interrelated, composed of the main objective down to the factors, then to the actor, the principals' goals, then the strategies and ultimately to the decision. (3) The preparation of an individual opinion matrix for each criterion and an alternative is done through pairwise comparisons. Each element of the system with other elements at each level of hierarchy in pairs is compared to obtain the value of interest elements quantitatively. Comparative values that have been done must be obtained level consistency with $\mathrm{CR} \leq$ $10 \%$.

e. The Relevant Research

1) Cristina Dai Prá Martens, Fabrício Martins Lacerda, Ana Claudia Belfort; and Henrique Mello Rodrigues de Freitas (2016)

Research on entrepreneurial orientation (EO) has attracted researchers' attention for over 30 years. The purpose of this paper is to comprehensively analyze the body of literature resulting from 30 years of research in $\mathrm{EO}$, and to answer the following questions: what are the major themes that have emerged? What areas are missing? What degree of convergence do we see in the field of EO, and what concepts/topics has the field converged around?

A bibliometric study with a sample of 405 articles published from January 1987 to July 2014 was developed. Techniques of bibliometric, lexical, and content analysis were used. The analysis involved: the evolution of published articles; the main authors, their nationalities, and institutional affiliations; citation and co-citations analysis; the 
journals that have published the most articles; and the most frequently-searched topics. Opting for bibliometric techniques permit an analysis of a larger number of articles and a greater variety of articles than other methodologies such as meta-analyses and systematic review studies. Accordingly, a more comprehensive look at the field of EO can be taken.

Two distinct but complementary classifications are proposed to characterize the body of the literature resulting from 30 years of research in EO. The first one demonstrates that the field presents a convergence of the themes in four axis which together comprise studies on EO: performance, strategy, entrepreneurial attitude, and management. The second one presents the frequency of occurrence of the themes in the field: highfrequency themes or classical themes, frequently in the literature; moderate-frequency themes or emerging issues have not been sufficiently explored; low-frequency themes or potential opportunities related to understudied issues and contexts less frequently surveyed. A future research agenda is proposed for emerging themes and specific contexts.

The identification of key themes in the field of EO contributes to assess the research evolution in order to recognize emerging themes and contexts, and the research gaps. With this, it is possible to lead new studies to cover a lack of research and advance knowledge in the field. The themes most studied also show the contribution for EO to organizational practice, espe- cially in relation to the impact on the performance, the stimulus to the development of innovations, and the effects on organizational growth. Additionally, the identification of the authors most cited, most productive on the theme and the identification of the core journals for publishing of the area is recommended as a general reference for researchers interested in the topic of EO.

Although EO literature has been widely developed in Anglo regions (especially in the USA and UK) and Germanic Europe (especially Spain), there are others lacking these studies, especially Latin America, subSaharan Africa, Eastern Europe, and Middle East, with rare articles published internationally. The results can guide the advancement of research in these different contexts and realities where even issues more widely treated in the literature have been unexplored. The lack of studies in certain contexts can lead to new studies for inserting new insights into EO, such as potential differences between developed regions and in development. For regions where the studies on EO are more developed, the results of this paper contribute to signaling issues and contexts little explored that may be the focus of attention.

The generation of literature indicators of EO through bibliometric fills a research gap on the theme, providing a more comprehensive view of the field and of the current status of the research on EO. Identifying the most frequent topics in EO literature, and little-explored themes and contexts makes it possible 
to propose an agenda for future research and knowledge generation on EO. Thus, it is suggested the development of studies focus on emerging themes like growth, learning, knowledge, resources, and capabilities; also in specific contexts with potential for aggregating new knowledges in the EO field such as family firms, non-profit organizations, social contexts, the public sector, university, spinoff, firms in emerging and developing economies

2) Zalina Ibrahim, Firdaus Abdullah, and Azman Ismail

Small and Medium Enterprises (SMEs) have always been an important contributor to a country's economic prosperity. In the globalization era, businesses are forced to push beyond the boundaries to sustain their competitive advantage and have the competency to succeed. Internationalization has become a way forward for businesses to increase performance and this move has open doors to SMEs to be in the picture. Studies on internationalized Small and Medium Enterprises (iSMEs) and international business competence in particular for the Internationalized Malaysian Small and Medium Enterprises (iMSMEs) are very limited. Therefore, this research explores into the world of competence for the internationalized Malaysian Small and Medium Enterprises (iMSMEs) by interviewing the Small and Medium Enterprises experts from the East and West of Malaysia. The experts' panels (RES) are divided into five categories: academicians, policy makers, supporting government agencies, chambers of commerce and industries. The research uses a thematic approach to identify themes and emergent themes; and intelligent coding to determine most influential factors; and reports each theme and sub-theme using percentage and supporting quotations. The research contributes on the new definition of competence, international business competence and international business competence indicators for internationalized Small and Medium Enterprises. In addition, implications of this study and directions for future research are also discussed.

3) Risky Farandi Pradana

Risky Farandi Pradana (2016), in this research is the analysis of what the most appropriate strategy used by SMEs Batik Zikin to increase sales volume. The purpose of this study was to determine whether the right marketing strategy. Type in this research is descriptive using qualitative research type. Descriptive research is research conducted to determine the value of a variable without making comparisons or connect with other variables. Technique data collecting by interview, observation and documentation. Based on the research results, the strength of batik Zikin is to have its own distinctive characteristics on motifs and colors, excellent product quality, fast innovation process is done, an experienced human resources, disciplined and have the skill, has the concept of effective work with consumers.

The weakness is the absence of patent protection, the price of expensive products, the lack of market expansion and promotion is done, the production process is 
not effective, the organizational culture has not been standardized and the absence of SOP. Opportunities that the needs of consumers increasingly high and not met the market, the market share of the increasingly widespread, the emergence of new technologies, a strategic marketing, the emergence of fashion trends turn very fast. The threat that many actors batik business in Pekalongan, increasing competition in terms of marketing, product price competition, changes in consumer tastes toward batik products, rising raw material prices cloth.

Advice for companies are SME's Batik Zikin must expand its business in all regions in Indonesia or overseas and improve the excellence product SME's Batik Zikin terms of product quality, the motive, the raw material prices and market expansion by opening branches in several cities strategically corner premium product as well as to follow actively the exhibition of fashion and batik that messages and promotion of the company can be conveyed directly by consumers and other things that need to be noticed by SME's batik Zikin is a trademark used also must have a patent that is not being misused by parties are not responsible for plowing the work of SMEs Batik Zikin. The Batik Zikin Structure of UKN organizations should be written in a systematic and structured to facilitate the workers to perform job responsibilities, create documents about the SOP (Standard Operational Procedure) on any part of the production or non-production, so that all these activities can be run effectively and efficiently so that all activities within the SME Batik Zikin may be optimized and consumer needs can be met appropriately.

\section{METHODOLOGY}

In this study was conducted using qualitative descriptive with a study carried out in the scope of local government (Municipality of Semarang and the Office of SMEs Semarang), the Professional (Dean and Lecturer Unissula Semarang) and 20 employers with the life of the business the longest and is considered to have an expert or representing all MSMEs engaged in the trade sector in the city of Semarang. Primary data was collected through interviews and questionnaires and secondary data obtained from relevant agencies with SMEs and relevant literature that is supported by the results of SocioEconomic Survey (Susenas) 20082013 were obtained from the Central Statistics Agency, Central Java (Central Java of BPS).

In this study, the discussion using SWOT analysis (Strength, Weakness, Opportunities, Threats). SWOT analysis is to identify the various factors systematically to formulate a organisasi.Analisis strategy is based on the logic that maximizes strength (Strength) and opportunities (opportunites), but simultaneously to minimize weakness (weakness) and threats (threats) .And further discussion using Analytical hierarchy Process (AHP) is a functional hierarchy of human perception with its main input. Through the hierarchy, a complex and unstructured problems can be broken down into groups and then organized into a hierarchical form (Permadi, 1992).

Strategic decision making process is always associated with the development of the mission, goals, strategies, and organizational policies. Thus, a strategic planner should ana- 
lyze the strategic factors of the organization in the current conditions is called situation analysis (Rangkuti, 2008).

\section{RESULTS AND DISCUSSION}

a. SWOT (Strength, Weakness, Opportunities, Threats)

1. The Government Rating

Table 4.1 SWOT Strategy Alternative Sequence

\begin{tabular}{|c|c|c|}
\hline PRIORITY & $\begin{array}{c}\text { STRATE- } \\
\text { GY }\end{array}$ & VALUE \\
\hline I & $\begin{array}{c}\text { Strength - } \\
\text { Opportunity }\end{array}$ & 14.36 \\
\hline II & $\begin{array}{c}\text { Strength - } \\
\text { Threat }\end{array}$ & 12.60 \\
\hline III & $\begin{array}{c}\text { Weakness - } \\
\text { Opportunity }\end{array}$ & 5.14 \\
\hline IV & $\begin{array}{c}\text { Weakness - } \\
\text { Threat }\end{array}$ & 3.38 \\
\hline
\end{tabular}

Table 4.2 Strategy Priority I : Strategy Strength \& Opportunity (SO)

\begin{tabular}{|c|c|c|c|}
\hline No. & STRENGTH & No. & OPPORTUNITY \\
\hline 1 & $\begin{array}{l}\text { The geographical position of Sema- } \\
\text { rang }\end{array}$ & 1 & $\begin{array}{l}\text { Undang-undang Pajak dan Retribusi baru No- } \\
\text { mor } 28 \text { Tahun } 2009\end{array}$ \\
\hline 2 & $\begin{array}{l}\text { The quality and quantity of human } \\
\text { resources in Semarang }\end{array}$ & 2 & $\begin{array}{l}\text { Undang-undang baru No. } 20 \text { Tahun } 2008 \text { ten- } \\
\text { tang UMKM }\end{array}$ \\
\hline 3 & $\begin{array}{l}\text { The government policy in terms of } \\
\text { ease of filing requirements of venture } \\
\text { capital }\end{array}$ & 3 & Social and political conditions of national \\
\hline 4 & $\begin{array}{l}\text { Facilities and infrastructure such as } \\
\text { the market economy and other eco- } \\
\text { nomic areas in Semarang }\end{array}$ & 4 & $\begin{array}{l}\text { Social and political conditions in Semarang } \\
\text { City }\end{array}$ \\
\hline 5 & $\begin{array}{l}\text { Capacity and institutional perfor- } \\
\text { mance in Semarang }\end{array}$ & 5 & Various programs of the central government \\
\hline 6 & $\begin{array}{l}\text { Efforts to socialize the potential are- } \\
\text { as of Semarang to outside parties } \\
\text { (private / investor) }\end{array}$ & 6 & $\begin{array}{l}\text { Central government support in the form of } \\
\text { transfers to the municipality Semarang }\end{array}$ \\
\hline 7 & $\begin{array}{l}\text { Availability of education in the city } \\
\text { of Semarang }\end{array}$ & 7 & Technology Advances \\
\hline & & 8 & $\begin{array}{l}\text { Law enforcement and bureaucratic reform that } \\
\text { is being promoted by the central government } \\
\text { Clothmaking }\end{array}$ \\
\hline & & 9 & Various outcomes are owned by the regions \\
\hline & & 10 & Private investment in the city of Semarang \\
\hline & & 11 & $\begin{array}{l}\text { Cooperation with regions around the city of } \\
\text { Semarang }\end{array}$ \\
\hline
\end{tabular}

* $\quad$ Strategy Of Empowerment Small And Medium Enterprises In The Effort For Increasing Revenue And Market.

* $\quad$ https://doi.org/10.21009/econosains.0161.04 


\begin{tabular}{|c|c|}
\hline \multicolumn{2}{|r|}{ SO (STRENGTH-OPPORTUNITY) STRATEGY } \\
\hline 1 & $\begin{array}{l}\text { With the support of the central government in the form of transfer, the city government can } \\
\text { maximize capital base that has been owned by the city of Semarang in developing the empow- } \\
\text { erment of SMEs in the city of Semarang, such as favorable geographical conditions, maximiz- } \\
\text { ing the potential of the quality and quantity of human resources are sufficient, means economic } \\
\text { and regional infrastructure that is already available, further maximize implementation of the } \\
\text { Act No. } 20 \text { of } 2008 \text { and the law on the financial balance of central and local, as well as balanc- } \\
\text { ing the implementation of tax laws and levies to the SME market conditions in the city of Se- } \\
\text { marang, in order to increase revenues and development of the city of Semarang, especially in } \\
\text { terms of the empowerment of SMEs }\end{array}$ \\
\hline 2 & $\begin{array}{l}\text { With the availability of infrastructure, economy owned by the city of Semarang, the govern- } \\
\text { ment can take advantage of the work ethic, tenacity and entrepreneurial soul community in the } \\
\text { micro economy sector to further strengthen the economy through small industries, SMEs and } \\
\text { cooperatives, in order to face the market competition Globalization }\end{array}$ \\
\hline 3 & $\begin{array}{l}\text { More maximizing government can work with the community in the city and areas surrounding } \\
\text { the city of Semarang is currently in the stage of developing areas or areas that have been devel- } \\
\text { oped to promote the potential of the area to outside parties (private / foreign), as well as the } \\
\text { reform of the bureaucracy simpler its workflow, law enforcement more firmly and correctly, } \\
\text { creating a political atmosphere in Semarang for more flexible and conducive to making the city } \\
\text { more attractive Semarang outside attention with more leverage to want to invest in developing } \\
\text { market share and revenue empowerment of SMEs in Semarang }\end{array}$ \\
\hline 4 & $\begin{array}{l}\text { Improving the quality of business production by using our technological progress, infrastruc- } \\
\text { ture education (training) is high quality, cooperation with the regions surrounding the city of } \\
\text { Semarang more closely in the operation of SMEs as one of the priorities of urban development } \\
\text { equitably to remote areas of the city Semarang supported by reform of the bureaucracy and law } \\
\text { enforcement are implemented Affirmative to grow revenue (PAD) and the structure of Sema- } \\
\text { rang city budget. }\end{array}$ \\
\hline 5 & $\begin{array}{l}\text { The city government make the program work on the ease of the application procedure venture } \\
\text { capital structure is not very bankable for micro entrepreneurs who want / have recently opened } \\
\text { its efforts to grow market share and revenue achieved by the UMKM as one pillar of economic } \\
\text { growth in the city of Semarang }\end{array}$ \\
\hline
\end{tabular}

SO strategy is the best strategic alternatives that have the highest weighting values, but not necessarily all of these strategies can be implemented simultaneously, so that should be a priority if the implementation is jointly meet the constraints of resources (resources constraints).

\section{Assessment of SME's Persons} From the results of the questionnaire weighting, then compiled the priority strategies based on a combination of strategies that have the highest value to the lowest.

Table 4.2 The SWOT Strategy Alternative Sequence

\begin{tabular}{|c|c|c|}
\hline PRIORITAS & STRATEGI & BOBOT NILAI \\
\hline I & Strength - Opportunity & 10.92 \\
\hline II & Strength - Threat & 7.86 \\
\hline III & Weakness - Opportunity & 5.33 \\
\hline IV & Weakness - Threat & 2.27 \\
\hline
\end{tabular}

The result of the interaction of IFAS - EFAS which produces 
strategies that got the most weight high is Strength - Opportunity (SO), which can be translated from the internal side, the city of Semarang has a greater strength than weaknesses, while the external side, the opportunities far outweigh the threat in or- der to implement the empowerment of SMEs in the city of Semarang. Strategy formulation is obtained through a combination of $\mathrm{S}, \mathrm{W}, \mathrm{O}$, and $\mathrm{T}$, resulting in some combination of strategies as shown in the table below.

Table 4.3 The Priority of Strategy : Strength \& Threats (ST) Strategy

\begin{tabular}{|c|c|c|c|}
\hline No. & STRENGTH & NO & THREATS \\
\hline 1 & $\begin{array}{l}\text { The quality and quantity of human } \\
\text { resources in Semarang }\end{array}$ & 1 & Tax Act and a new Retribution No. 28 of 2009 \\
\hline 2 & $\begin{array}{l}\text { Work ethic, toughness and entrepre- } \\
\text { neurial spirit of the people in the } \\
\text { micro economy sector }\end{array}$ & 2 & $\begin{array}{l}\text { free market globalization and the openness of } \\
\text { the world economy }\end{array}$ \\
\hline 3 & The level of community participation & 3 & $\begin{array}{l}\text { the signing of a free trade agreement between } \\
\text { the government of Indonesia with the Chinese } \\
\text { government and other foreign governments }\end{array}$ \\
\hline 4 & $\begin{array}{l}\text { Equitable distribution of develop- } \\
\text { ment results in Semarang }\end{array}$ & & \\
\hline 5 & $\begin{array}{l}\text { Efforts to socialize the potential area } \\
\text { of Semarang city to outsiders } \\
\text { (investors / private) }\end{array}$ & & \\
\hline 6 & $\begin{array}{l}\text { Effect of capital structure and in- } \\
\text { come level }\end{array}$ & & \\
\hline 7 & $\begin{array}{l}\text { Availability of educational advice in } \\
\text { Semarang }\end{array}$ & & \\
\hline 8 & $\begin{array}{l}\text { Influence the quality of the produc- } \\
\text { tion efforts on the growth of SMEs } \\
\text { in Semarang }\end{array}$ & & \\
\hline \multicolumn{4}{|c|}{ ST (STRENGTH-THREAT) STRATEGY } \\
\hline 1 & \multicolumn{3}{|c|}{$\begin{array}{l}\text { Maximize the potential of the quality of SME business, improve the quality and quantity of } \\
\text { human resources with adequate educational facilities that have been provided, further maxim- } \\
\text { ize community participation in overseeing the development of economies in Semarang to face } \\
\text { globalization, open markets, and the openness of the world economy }\end{array}$} \\
\hline 2 & \multicolumn{3}{|c|}{$\begin{array}{l}\text { Promoting the potential that exists in the city of Semarang, one of which is the potential of hu- } \\
\text { man resources of high work ethic, perseverance and a great entrepreneurial in attracting inves- } \\
\text { tors to Semarang }\end{array}$} \\
\hline 3 & \multicolumn{3}{|c|}{$\begin{array}{l}\text { Improve the results of urban development such as public facilities / infrastructure economy } \\
\text { (traditional markets and modern markets, accessibility areas, facilities for electricity, telephone, } \\
\text { and the availability of clean water) quality that can be felt as a whole to various remote areas } \\
\text { which are potential areas craftsman / entrepreneur SMEs in semarang city in facing the World } \\
\text { Globalization to create the operational and production business (goods / services) competitive } \\
\text { business that is superior compared with products from abroad, especially from China }\end{array}$} \\
\hline 4 & \multicolumn{3}{|c|}{$\begin{array}{l}\text { To grow a potential revenue and capital structure MSME entrepreneurs in Semarang with sim- } \\
\text { plified procedures venture capital investment and the restructuring of segments of society im- } \\
\text { posed a tax payer of tax laws and Retribution No.28 of } 2009\end{array}$} \\
\hline
\end{tabular}

* $\quad$ Strategy Of Empowerment Small And Medium Enterprises In The Effort For Increasing Revenue And Market. 
b. AHP (Analythical Hierarchy Process)

Table 4.4 AHP (Analythical Hierarchy Process) Strategy

\begin{tabular}{|l|l|c|}
\hline LEVEL & \multicolumn{1}{|c|}{ DEFINITION } & VALUE \\
\hline 1 & Scenario & 0,681 \\
\hline & Optimistic & 0,194 \\
\hline & The Status Quo & 0,151 \\
\hline & Pesimistic & 0,290 \\
\hline & Objectives & 0,285 \\
\hline & Increase Revenue & 0,450 \\
\hline & Improve Marketing Growth & 0,294 \\
\hline & $\begin{array}{l}\text { Improve product quality and } \\
\text { personality of Micro SME en- } \\
\text { trepreneurs }\end{array}$ & 0,264 \\
\hline & Strategy & $\begin{array}{l}\text { Improving Managerial skills } \\
\text { (human resources, financial, } \\
\text { and operational techniques) }\end{array}$ \\
\hline & Growing Market Share & 0,187 \\
\hline & To optimize the business capital & 0,184 \\
\hline & $\begin{array}{l}\text { Ease of acquisition of raw ma- } \\
\text { terials }\end{array}$ & Maintain a healthy competition \\
\hline & & \\
\hline
\end{tabular}

Based on data processing using AHP metode, to achieve the target of increasing revenue and market expansion of SMEs in the city of Semarang, obtained priority regional development policy strategy as follows :

1) Improving the managerial skills by improving capacity, work ethic, and the performance of institutions and staff of the local government of Semarang, and increase the participation of the community (MSMEs) in the planning, implementation and supervision of the construction of micro enterprises and small and medium.

\section{(Priority I)}

2) Growing market share / marketing efforts done by the govern- ment of Semarang cooperate more closely than ever before with the governments of other regions in Central Java province, non Central Java province, and the central government with a bureaucratic system that is clean and consistent.

(Priority II).

3) The government through the Ministry of Cooperatives and SMEs this year allocating venture capital or startup capital for entrepreneurs beginners are expected to reach 2,160 people from 33 provinces in Indonesia to encourage SMEs in order to raise the eligibility and capability, so bankable in managing his/her business like expected by the Government in

* $\quad$ Strategy Of Empowerment Small And Medium Enterprises In The Effort For Increasing Revenue And Market. 
an effort to increase revenue and the expansion of markets in the city, or can be simplified in the hierarchy into optimizing working capital. (Priority III).

\section{CONCLUSION}

a. Managerial Implication

1) SWOT Analysis

a) With the support of the central government in the form of transfer, the city government can maximize capital base that has been owned by the city of Semarang in developing the empowerment of SMEs in Semarang;

b) With the availability of infrastructure, economy owned by the city of Semarang, the government can take advantage of the work ethic, tenacity and entrepreneurial soul community in the micro economy sector to further strengthen the economy through small industries, SMEs and cooperatives, in order to face the globalization of market competition;

c) More maximizing community participation in planning, implementation, and monitoring of economic development in the city of Semarang;

d) Improving the quality of business production facilities using the technology advances, education infrastructure (training) were high quality;

e) The city government make the program work on the ease of filing of the venture capital structure is not very bankable for micro entrepreneurs who want / have recently opened its efforts to grow market share and revenue achieved by the MSMEs as one pillar of eco- nomic growth in the city of Semarang.

2) Priority Development Policy (AHP)

a) Improvement of managerial skills by improving capacity, work ethic, and the performance of institutions and staff of the local government of Semarang, and increase the participation of the community (MSMEs) in the planning, implementation and supervision of the construction of small and medium micro enterprises;

b) The Government of Semarang cooperate more closely than ever before with the governments of other regions in Central Java province, non Central Java province, and the central government with a bureaucratic system that is clean and consistent and often hold exhibitions cooperation of SMEs both local, national and international levels;

c) More maximize the implementation of regional autonomy laws and laws on the central and local financial balance by making areas in the city of Semarang as a sub-district / regional business interests Global Brand;

d) The government should increase the percentage of Semarang city local budget allocation in the future for venture capital for entrepreneurs beginner to encourage SMEs in order to raise the eligibility and capability;

e) The Government of Semarang city should help ease of obtaining raw materials procurement is always smooth and can be controlled by both in terms of location, price, and new raw

* $\quad$ Strategy Of Empowerment Small And Medium Enterprises In The Effort For Increasing Revenue And Market. 
materials

b. Suggestion

Despite all the weaknesses, suggestions that can convey the author for further research is to add the respondents are more varied, for example by adding the business sector SMEs.

\section{REFERENCE}

1. Book

David, Fred R. (2006). Manajemen Strategi. Book 1, 10th Edition. Jakarta : Salemba Empat.

Gluek, William F dan Jauch, Lawrence R. 2000. Manajemen Strategis dan Kebijakan Perusahaan, Erlangga, Jakarta

Ma'arif, M. S., and Tanjung, $\mathrm{H}$. (2003). Teknik-teknik Kuantitatif untuk Manajemen. Jakarta : Grasindo.

Permadi, B.S. (1992). AHP. PAUEK, UI, Jakarta.

Rangkuti, Freddy. (2008). Analisis SWOT Teknik Membedah Kasus Bisnis. Jakarta : PT. Gramedia Pustaka Utama.

Winardi. (2000). Kepemimpinan dalam Manajemen. Jakarta : PT. Rieneka Cipta.

2. Peraturan Pemerintah / PerundangUndangan

The Government of the Republik of Indonesia. (2008) Law No. 20 Year 2008 on Micro, Small and Medium Business. Chapter IV. Article 6. Jakarta.

\section{Online Documents}

Cristina Dai Prá Martens, Fabrício Martins Lacerda, Ana Claudia Belfort and Henrique Mello Rodrigues de Freitas. (2016). Research on Entrepreneurial Orientation: Current Status and Future Agenda. International Journal of Entrepreneurial Behavior \& Research 22:4, 556-583. DOI : $\quad \underline{\text { http:// }}$ dx.doi.org/10.1108/IJEBR08-2015-0183 (Access Date : 10 January 2017)

Munizu.M. 2010. Pengaruh FaktorFaktor Eksternal dan Internal Terhadap Kinerja Usaha Mikro dan Kecil (UMK) di Sulawesi Selatan. Journal of Management and Entrepreneurship, VOL.12, NO. 1, page 33-41. (Access Date : 12 November 2016)

Zalina Ibrahim, Firdaus Abdullah, and Azman Ismail. (2016). International Business Competence and Small and Medium Enterprises. Procedia Social and Behavioral Sciences Volume 224, 15 June 2016, Pages 393-400. DOI : http://dx.doi.org/10.1016/ j.sbspro.2016.05.402 (Access Date : 13 January 2017)

Pradana, Farandi Risky. (2016). Analisis Strategi Bisnis Menggunakan Metode SWOT (Studi pada UKM Batik Zikin Pekalongan). Other thesis, UPN "Veteran" Yogyakarta. DOI : $\quad$ http:// eprints.upnyk.ac.id/4835/ (Access date : 11 January 2017) 